Praca oryginalna/Original research article

\title{
Oczekiwania wobec leczenia u chorych w wieku 60+ leczonych chemioterapią dożylną z powodu nowotworowych chorób hematologicznych - ocena w trakcie leczenia
}

\section{Patients expectations toward treatment analyzed in a group of patients over sixty years old treated with intravenous chemotherapy due to hematological malignancies. Evaluation done during the period of treatment}

\author{
Barbara Zawadzka ${ }^{1,2, *}$, Barbara Grabowska ${ }^{2}$, Małgorzata Raźny ${ }^{2}$, Sara Zawadzka ${ }^{3}$ \\ ${ }^{1}$ Zakład Polityki Zdrowotnej i Zarządzania, Instytut Zdrowia Publicznego UJ, Collegium Medicum, Kraków, Poland \\ ${ }^{2}$ Oddział Hematologii i Chorób Wewnętrznych Szpital Specjalistyczny im. L. Rydygiera, Kraków, Poland \\ ${ }^{3}$ Wydział Lekarski, WUM, Warszawa, Poland
}

IN F ORMACJE O ARTYKULE

Historia artykułu:

Otrzymano: 15.01.2013

Zaakceptowano: 23.01.2013

Dostępne online: 16.03.2013

Słowa kluczowe:

- chemioterapia dożylna

- ludzie starsi

- oczekiwania

- adaptacja

Keywords:

- Intravenous chemotherapy

- Elderly people

- Expectations

- Adaptation

\section{A B S T R A C T}

Great expectations of chemotherapy have a significant impact on health activities. Patients relay their opinion on their positive self-assessment perceived with psychophysical capacity, clinical symptoms of the disease and the quality of medical actions. The expectation analysis of elderly patients who undergo intravenous chemotherapy was the objective of this paper.

Research was performed in 2012. There were 30 patients of age 60 and more included. All patients were treated in Haematology Ward of District Hospital in Kraków. A questionnaire, ECOG scale, and 5 Juczyński tests were used in order to evaluate the psychophysical capacity of patients. The Juczyński tests measure selected psychological resources which influence on the adaptation of an organism to the disease and treatment. These are: optimism (LOT-R), satisfaction from life (SWLS), sense of self effectiveness (GSES), the degree of disease approval (AIS) and emotional control (CECS).

Significant relations between psychophysical capacity and objective effects of treatment and subjective self-assessment of the state of one health were found. Better functioning of patients (measured by ECOG scale) is strictly correlated with good adjustment and acknowledgment of illness limitations $(p=0.022)$. Patients having good sense of self-satisfaction suffer from different ailments less severely $(p=0.039)$ and expect less intensification of bad syndromes in future $(p=0.06)$. On the other hand those who are overcome with fear anticipate more troubles after chemotherapy $(\mathrm{p}=0.024)$.

Based on the results of analysis the distribution of patients' expectations towards their family, medical caregivers and the process of treatment was obtained. The picture

\footnotetext{
* Adres do korespondencji: Oddział Hematologii i Chorób Wewnętrznych Szpital Specjalistyczny im. L. Rydygiera, os. Złotej Jesieni 1, 31-826 Kraków. Tel.: +504-876-957.

Adres email: bazawadzka@gmail.com (B. Zawadzka). 
of illness dynamics was presented using two categories: objective (medical) and subjective described by patients evaluations of their state of health during treatment.

The research revealed the necessity of analyzing psychophysical functioning of elderly submitted to long treatment.

(C) 2013 Polskie Towarzystwo Hematologów i Transfuzjologów, Instytut Hematologii i Transfuzjologii. Published by Elsevier Urban \& Partner Sp. z o.o. All rights reserved.

Nikt nie jest tak stary, aby nie wierzył, że może żyć jeszcze parę lat dłużej.

Cyceron

\section{Wprowadzenie}

O starości staramy się nie myśleć, a jeśli już myślimy, to z niepokojem. Rzadko zastanawiamy się nad tym, że taka postawa wynika z panującej w naszej materialnej kulturze opinii społecznej, a tym samym, że możliwe jest spojrzenie odmienne. Każdy wiek ma swoje walory, a starość, która jest czasem pełnej dojrzałości, może być spostrzegana jako cnota. Różne oblicza pokazuje starość: niejeden człowiek potrafi być aktywny jak w młodości, inny poddaje się starczym ograniczeniom, a jeszcze następny, zdając sobie sprawę ze swoich słabości, wykorzystuje pozostałe mu możliwości i podejmuje zadania adekwatne do swoich sił. Potrafi ciągle tworzyć, rozwijać nowe zamiłowania, uzdolnienia i czuć się potrzebny w życiu [1, 2]. W dobie starzejącej się populacji rośnie zatem zapotrzebowanie na skuteczne oddziaływania medyczne dopasowane do potrzeb i możliwości osób starszych. W badaniach coraz częściej podnoszona jest kwestia przesuwania granic wiekowych w zakresie realizacji wielu procesów leczniczych, wcześniej rezerwowanych tylko dla ludzi poniżej wieku określanego jako wiek progowy dla starości. Poszukiwania badawcze podążają w różnych, komplementarnych kierunkach. Jeden z nich dotyczy mechanizmów funkcjonowania charakterystycznych dla ostatniego w biegu życia okresu rozwojowego człowieka. Inny zmierza do określenia uniwersalnych cech, które nie podlegają zmianom w procesie starzenia się. Analizy prowadzone są $\mathrm{w}$ celu poznania prawidłowości fizycznych i psychologicznych, aby w konsekwencji uwzględniać psychofizyczny dobrostan człowieka [3].

Współczesna nauka sprawia, że wzrasta wyleczalność w grupie chorych na nowotwory. Widać to szczególnie $\mathrm{w}$ ciągu ostatnich 20 lat w dziedzinie hematoonkologii, gdzie wprowadzenie nowych leków, takich jak przeciwciała monoklonalne czy inhibitory kinaz, spowodowało uzyskanie poprawy tolerancji leczenia i możliwość zredukowania dawek leków cytostatycznych [4]. Dotyczy to także prowadzenia terapii u pacjentów w starszym wieku dodatkowo obciążonych schorzeniami i zmniejszoną wydolnością różnych narządów.

Nowoczesne sposoby leczenia nie są całkowicie pozbawione wad. Nadal niosą ze sobą możliwość działań niepożądanych leków, wymagają prowadzenia równocześnie leczenia wspomagającego w zapobieganiu i leczeniu ewentualnych powikłań. Ludzie starsi dużo częściej i dobitniej odczuwają skutki uboczne terapii. Wynika to częściowo z obniżonej wydolności narządowej, głównie układu krążenia, która osłabia funkcję nerek. Inną przyczynę spostrzega się we współistnieniu interakcji lekowych, bowiem często diagnozowana jest $\mathrm{w}$ wieku starszym polipragmazja wynikająca z współwystępowania wielu chorób.

Prowadzenie radykalnej chemioterapii w chorobach hematologicznych skutkuje zaburzeniami krwiotworzenia, w efekcie których powstają objawowe cytopenie. Według doniesień badaczy amerykańskich [5], obniżenie poziomu hemoglobiny poniżej $10 \mathrm{~g} / \mathrm{l}$ powoduje znamienne zaburzenia funkcji poznawczych ośrodkowego układu nerwowego, zaburzenia snu, wywiera także niekorzystny wpływ na układ sercowo-naczyniowy, pokarmowy, odpornościowy [6]. Zaburzenia liczby i funkcji płytek krwi niosą ryzyko groźnych dla życia powikłań zakrzepowych i zatorowych lub nagłych wylewów i krwotoków. Spadek liczby białych krwinek wyrażony znamienną neutropenią wielokrotnie zwiększa ryzyko wystąpienia trudnych do wyleczenia uogólnionych infekcji. Jeśli pod wpływem stosowanych środków choroba nowotworowa nie wchodzi w regresję, stosowane są kolejne linie leczenia. Zaawansowana choroba nowotworowa w wyniku działania cytokin uwalnianych przez nowotwór i tkanki chorego, doprowadza do rozwoju zespołu CAA (caheksja-anoreksja-astenia) objawiającego się wzmożoną potliwością, brakiem apetytu, zanikiem mięśni, spadkiem wagi ciała, a w konsekwencji znacznym osłabieniem. Często dołącza się do tego zespołu objawów ból i ogólne wyczerpanie psychofizyczne. Szacuje się, że brak łaknienia występuje u ok. 50\% chorych na nowotwór [6]. Prowadzenie chemioterapii bez adekwatnego leczenia wspomagającego niejednokrotnie nasila objawy zespołu wyniszczenia.

W badaniach nad funkcjonowaniem ludzi poddawanych obciążającemu leczeniu ciągle dominuje ukierunkowanie na rozpoznawanie deficytów związanych z takimi negatywnymi reakcjami psychologicznymi jak wycofanie, poczucie bezradności, lęk etc. [7]. Takie jednostronne (patogenetyczne) podejście do człowieka chorego zaczyna być równoważone docenianiem jego zasobów jako bardzo ważnych w ochronie zdrowia i kształtowaniu zachowań zdrowotnych. Prace Antonowsky'ego [8], Csikszentmihalyi'a [9], Zimbardo [10], Seligmana [11], akceptujące salutogenetyczny obraz człowieka, uwzględniają jego prawo do odczuwania potrzeb, ale też szczęścia i innych pozytywnych emocji, również w krytycznych sytuacjach życiowych. Chroniące zdrowie zasoby warunkują kształt potrzeb chorego, oczekiwania wobec leczenia, umiejętności radzenia sobie $\mathrm{z}$ trudami leczenia, nawrotami choroby, a nawet $\mathrm{z}$ nieskuteczną terapią [12].

\section{Cel pracy i pytania badawcze}

Celem pracy była analiza oczekiwań wobec leczenia starszych pacjentów w trakcie stosowania chemioterapii dożylnej. 
Zdecydowano się ją przeprowadzić poprzez odpowiedzi na następujące pytania:

1. Jak kształtują się zasoby psychologiczne chorych w wieku $60+$ leczonych dożylną chemioterapią?

2. Jakich zachowań od personelu i rodziny najczęściej oczekują badani?

3. Czy można określić dynamikę choroby i leczenia w badanej grupie?

4. Czy obiektywnie stwierdzone zmiany w zakresie sprawności są związane $\mathrm{z}$ nasileniem określonego parametru funkcjonowania psychologicznego?

5. Czy istnieje związek między medycznymi wskaźnikami zaawansowania choroby a oczekiwaniami pacjentów wobec leczenia?

6. Czy istnieje związek między obiektywnymi objawami skutków choroby i leczenia a wybranymi parametrami funkcjonowania psychologicznego?

\section{Uczestnicy badań i metody badawcze}

Badania zostały przeprowadzone w 2012 roku wśród pacjentów znajdujących się w trakcie leczenia przeciwnowotworowego w Oddziale Chorób Wewnętrznych i Hematologii Specjalistycznego Szpitala im. L. Rydygiera w Krakowie. Zastosowano dwa kryteria doboru pacjentów do grupy badawczej: ukończone 60 lat życia oraz stosowanie techniki leczniczej chemioterapii dożylnej. Przebadano 30 osób w wieku 60-85 lat, w tym 16 kobiet oraz 14 mężczyzn. Średnia wieku wyniosła 70,3 roku. W badanej grupie było 9 osób z wykształceniem wyższym, 10 z wykształceniem średnim oraz 11 osób z wykształceniem podstawowym i zawodowym. Wszyscy badani są emerytami i mieszkają z minimum jedną osobą.

U chorych rozpoznano następujące choroby hematologiczne: białaczka, szpiczak, chłoniak, zespół mielodysplastyczny. Wobec 17 (57\%) osób stosowano I linię leczenia, wobec 9 (30\%) - II, a wobec 4 (13\%) - III linię leczenia chemioterapią dożylną.

W celu dokonania oceny medycznej ogólnego stanu fizycznego pacjentów - stanu sprawności i jakości życia, posłużono się skalą ECOG [13]. Obejmuje ona oceny od 0 do 5, przy czym 0 oznacza sprawność prawidłową i zdolność do samodzielnego wykonywania codziennych czynności, zaś 5 - zgon. Pomiar tą skalą zastosowano dwukrotnie przed rozpoczęciem leczenia oraz aktualnie - podczas wykonywania badania. Obliczono różnicę między wynikami i uzyskano dodatkowy wymiar $\Delta$ ECOG dający informację o obiektywnej poprawie, pogorszeniu lub braku zmiany w zakresie funkcjonalności pacjenta.

W badaniach analizowano wybrane aspekty funkcjonowania psychologicznego. W tym celu posłużono się ankietą skonstruowaną na potrzeby badania. Uwzględniono w niej 1 pytanie otwarte dotyczące marzeń, 4 pytania zamknięte mierzące oczekiwania i potrzeby pacjentów wobec rodziny i personelu medycznego oraz 1 zamknięte zawierające najczęstsze obawy chorych.

Zastosowano także testy w adaptacji Juczyńskiego [14], które mierzą wybrane zasoby psychologiczne mające wpływ na adaptację do choroby i leczenia: optymizm (Test Orientacji
Życiowej; LOT-R), satysfakcję z życia (Skala Satysfakcji z Życia; SWLS), poczucie własnej skuteczności (Skala Uogólnionej Własnej Skuteczności; GSES), stopień akceptacji choroby (Skala Akceptacji Choroby; AIS), kontrolę emocjonalną (Skala Kontroli Emocji; CECS). Interpretację wyników testów LOT-R, GSES i SWLS oparto na wynikach skali stenowej, natomiast testów AIS i CECS - porównując wyniki ze średnimi wskaźnikami grup odniesienia, zgodnie z sugestią autora adaptacji [14].

Analizę statystyczną przeprowadzono w programach Statistica Stats Soft Version 10, Stats Direct, statistical software, Version 2,7.2 (2008.09.06). Obliczono podstawowe parametry statystyczne w celu wykonania statystyki opisowej dla całej grupy. W celu dokonania porównania w grupie względem wybranych cech wykorzystano analizę wariancji ANOVA. Określając poziom zależności liniowej między zmiennymi, obliczono współczynnik korelacji Pearsona, który pozwolił na określenie poziomów istotności i kierunku uzyskanych zależności.

\section{Wyniki}

Prezentację wyników rozpoczęto od scharakteryzowania grupy badanej pod względem wybranych aspektów funkcjonowania psychologicznego i fizycznego (Tab. I). Średnie wyniki przebadanej grupy 30 osób leczonych chemioterapią dożylną mówią o przeciętnym lub nieco ponadprzeciętnym nasileniu zasobów osobowych określających charakter funkcjonowania psychologicznego. Grupę cechuje optymizm, rozumiany jako zgeneralizowane oczekiwanie pozytywnych zdarzeń. Takie ukierunkowanie życiowe wpływa pozytywnie na samopoczucie badanych i wskazuje na ich odporność na stresujące wydarzenia życiowe.

W teście AIS choroba jest pojmowana w kategoriach ograniczeń, głównie braku samowystarczalności, poczucia zależności od innych osób oraz obniżonego poczucia własnej wartości. Wyniki wskaźnika akceptacji choroby lokują się w górnych granicach średnich uzyskanych w innych grupach odniesienia. Świadczy to o tym, że pacjenci hematologiczni akceptują uciążliwości choroby. Jako przeciętne spostrzegają własne zasoby w sytuacji stresowej, szczególnie siłę zaangażowania (6 stenów). Mają także przekonanie o skuteczności radzenia sobie $z$ trudnymi sytuacjami i przeszkodami (7 stenów). Nawet w obliczu porażek nie przestają być zadowoleni $\mathrm{z}$ dotychczasowego życia, a ich

Tabela I - Charakterystyka grupy badanej pod względem wybranych aspektów funkcjonowania psychologicznego $(\mathbf{N}=\mathbf{3 0})$

Table I - Characteristics of the study group in terms of selected aspects of psychological functioning $(\mathbf{N}=30)$

\begin{tabular}{llrrrc}
\hline 1. & \multicolumn{1}{c}{ ŚREDNIA } & SD & MIN & ME & MAX \\
\hline AIS & 24,4 & 6,3 & 8 & 26 & 33 \\
LOT-R & 15,4 (6 stenów) & 6,2 & 8 & 15,5 & 24 \\
GSES & 29,6 (7 stenów) & 5,5 & 18 & 28,5 & 45 \\
CECS og & 53,9 & 10,8 & 30 & 54 & 73 \\
CECS G & 17,3 & 4,8 & 8 & 18 & 28 \\
\hline
\end{tabular}


Tabela II - Charakterystyka badanej grupy w kontekście oczekiwań wobec zachowań personelu i rodziny Table II - Characteristics of the study group in the context of the expectations of the behavior of the staff and families

\begin{tabular}{|c|c|c|c|}
\hline Oczekiwania wobec rodziny & liczba osób (\%) & Oczekiwania wobec personelu & liczba osób (\%) \\
\hline troski & $6(20 \%)$ & $\begin{array}{l}\text { rzeczowej informacji o chorobie, rokowaniu } \\
\text { i perspektywach w procesie leczenia }\end{array}$ & $7(23 \%)$ \\
\hline życzliwej obecności & - & $\begin{array}{l}\text { praktycznych zabiegów opiekuńczych oraz } \\
\text { leczniczych }\end{array}$ & - \\
\hline $\begin{array}{l}\text { praktycznej pomocy (dostarczenie jedzenia, } \\
\text { zmiana ubrania, etc.) }\end{array}$ & $3(10 \%)$ & $\begin{array}{l}\text { fachowości przejawiającej się w bezboleśnie } \\
\text { prowadzonych interwencjach }\end{array}$ & $3(10 \%)$ \\
\hline rozmowy na tematy związane z życiem domowym & $12(40 \%)$ & troski i życzliwości, & $8(27 \%)$ \\
\hline $\begin{array}{l}\text { rozmowy na tematy neutralne, np. o sporcie, } \\
\text { gospodarce, polityce }\end{array}$ & $1(3 \%)$ & żartów, uśmiechu & - \\
\hline $\begin{array}{l}\text { rozmowy o problemach związanych z chorobą } \\
\text { i leczeniem }\end{array}$ & $1(3 \%)$ & $\begin{array}{l}\text { rozmowy o problemach związanych z chorobą } \\
\text { i leczeniem }\end{array}$ & $2(7 \%)$ \\
\hline $\begin{array}{l}\text { możliwości ujawnienia swoich lęków, obaw, } \\
\text { potrzeb i pragnień }\end{array}$ & $7(23 \%)$ & $\begin{array}{l}\text { możliwości ujawnienia swoich lęków, obaw, } \\
\text { potrzeb i pragnień }\end{array}$ & $10(33 \%)$ \\
\hline
\end{tabular}

poziom satysfakcji z istnienia lokuje się na poziomie śred$\operatorname{nim}$ (7 stenów).

Grupę charakteryzuje dość wysoki poziom kontroli emocji $(53,9)$, w porównaniu $\mathrm{z}$ poziomami występującymi w innych grupach chorych somatycznie. Oznacza to, że pacjenci we własnej ocenie potrafią panować nad wyrazami badanych emocji: lęku, gniewu i depresji.

Pierwsze zagadnienie ankiety dotyczyło tematyki marzeń, które identyfikują u siebie pacjenci. 22 osoby (73\%) na pierwszym miejscu umieściły marzenie o swoim powrocie do zdrowia. W następnej kolejności wymieniane były pragnienia zdrowia i powodzenia dla członków najbliższej rodziny (76\% badanych). Pozostałe pragnienia dotyczyły powrotu do sił i sprawności (20\%), pomyślnego leczenia (10\%) oraz szczęścia, bycia kochanym, dobrego życia na stare lata. Jedna osoba marzyła o pieniądzach (3\%).

Dalsza część ankiety dotyczyła oczekiwań pacjentów wobec leczenia. 29 osób (97\%) zaznaczyło, że pragną być informowane o wynikach badań i leczeniu wspólnie z rodziną. Tylko jedna osoba (3\%) życzyła sobie, aby wyłącznie $\mathrm{z}$ nią samą rozmawiać o jej zdrowiu.

Opis oczekiwań pacjentów wobec rodziny i personelu zawiera tabela II. Wynika z niej, że większość chorych pragnie od bliskich rozmów na tematy związane z życiem domowym (40\%), możliwości ujawniania swoich obaw i potrzeb (23\%) oraz wyrazów troski (20\%). Niewiele osób zaznaczyło, że zależy im na rozmowach o leczeniu (3\%) lub na praktycznej pomocy (10\%). Od personelu medycznego najwięcej osób oczekuje otrzymania przestrzeni do ujawnienia swoich obaw i potrzeb (33\%), troski i życzliwości (27\%) oraz rzeczowych informacji (23\%). Niewielu pacjentów zaznaczyło, że chciałoby rozmów o problemach związanych z leczeniem (7\%).

W ankiecie ujęto 3 twierdzenia mające ujawnić obawy i troski pacjentów. Pacjenci mieli oceniać, jak często dręczą ich wybrane problemy. Myśli typu „mam już dość szpitala, nie chcę więcej tego obciążającego leczenia" zostały ocenione jako rzadko występujące przez 53\% chorych. 4 osoby (13\%) przyznają, że często myślą w ten sposób. „Chcę już tylko być w domu, z rodziną..." rzadko występują u $40 \%$ chorych, zaś przeciętnie u 53\%. Nikt z badanych nie myśli w ten sposób często. „Choroba zrujnowała mnie finansowo (nie mam pieniędzy)" dręczą często 4 osoby (13\%), 2 osoby przeciętnie, zaś rzadko lub wcale nie dotyczą one $80 \%$ pacjentów.

W ramach określenia, jak badani spostrzegają przebieg swojej choroby na przestrzeni czasu, zbadano ich oceny nasilenia uciążliwości choroby nowotworowej trzykrotnie w okresie chorowania. Pacjenci oceniali 5 objawów klinicznych na skali 10-stopniowej, co dawało możliwość uzyskania wyników w przedziale 0-50 punktów. Wyniki wypowiedzi pokazuje tabela III. Średnie ocen nasilenia dolegliwości z okresu wczesnej choroby (czas diagnozowania) wskazują na niezbyt duże ich nasilenie (śr. $=16,5$ ). Jeszcze słabiej badani odczuwają niedogodności choroby aktualnie - podczas leczenia chemioterapią (śr. =15,1). Spodziewają się zdecydowanego osłabienia dolegliwości po zakończeniu leczenia (śr. = 5,2). Różnice w subiektywnych ocenach zmian stanu zdrowia na przestrzeni leczenia w badanej grupie przedstawia rycina 1 . Z wykresu wynika, że zmian między

Tabela III - Wyniki średnie skali dotyczącej subiektywnych ocen stanu zdrowia w zakresie 5 objawów klinicznych choroby nowotworowej: oslabienie, wzrost potliwości, brak apetytu, spadek wagi ciala, ból i inne dolegliwości ( $\mathbf{N}=30)$

Table III - Medium-scale results on subjective assessments of health status in the 5 clinical symptoms of cancer: weakness, increased sweating, loss of appetite, weight loss, pain and other disorders $(\mathbf{N}=30)$

\begin{tabular}{lcccc}
\hline Oceny (skala 0-10) & ŚREDNIA & SD & MIN & ME \\
\hline Ocena A (przeszłości) & 16,5 & 11,8 & 0 & 13,5 \\
Ocena B (teraźniejszości) & 15,1 & 8,8 & 0 & 45 \\
Ocena C (przyszłości) & 5,2 & 7,4 & 0 & 29 \\
\hline
\end{tabular}




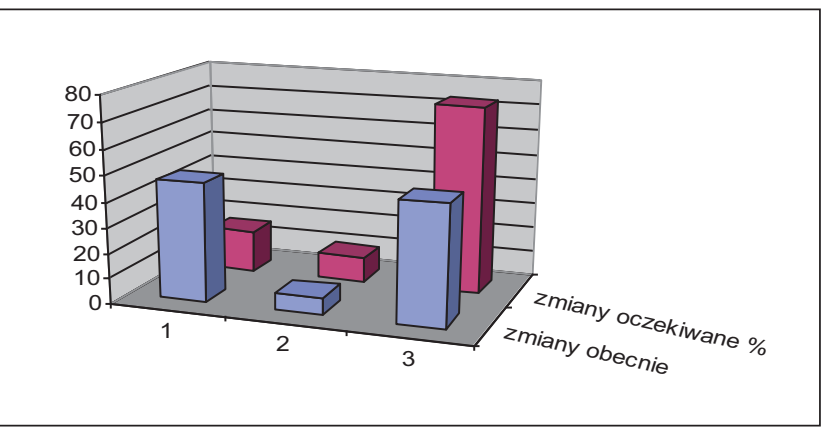

Ryc. 1 - Różnice w subiektywnych ocenach zmian stanu zdrowia na przestrzeni leczenia $w$ badanej grupie: 1 - pogorszenie, 2 - bez zmian, 3 - poprawa stanu zdrowia Fig. 1 - Differences in subjective assessments of changes in health status over the treatment in the study group: 1 - worsening, 2 - no change, 3 - to improve the health

stanem klinicznym $\mathrm{z}$ początku leczenia (A) i aktualnym (B) nie spostrzega 2 badanych (7\%). 14 osób (47\%) odczuwa pogorszenie swojego stanu fizycznego, tyle samo - poprawę. Nieco inaczej kształtują się oczekiwania, które zostały określone przez porównanie aktualnego nasilenia 5 objawów klinicznych choroby nowotworowej (B) z przewidywanym (C) - po zakończeniu leczenia. 3 osoby (10\%) nie oczekują zmian. Poprawy spodziewa się 22 osób (73\%), zaś pogorszenie stanu zdrowia po chemioterapii przewiduje 5 badanych (17\%).

W celu zobrazowania dynamiki choroby z użyciem parametrów medycznych zestawiono w tabeli IV wyniki sprawności funkcjonowania fizycznego mierzonego skalą ECOG oraz linii leczenia. $\mathrm{Z}$ tabeli wynika, że przed rozpoczęciem leczenia prawidłową sprawność wykazywało 6 osób (20\%). 12 pacjentów (40\%) w niewielkim stopniu przejawiało ograniczenie objawami choroby. Opieka personelu była niezbędna wobec 4 chorych (13\%). Oceny dokonane w trakcie leczenia wskazują, że pogorszenie funkcjonowania nastąpiło u 5 osób (17\%), zmiany nie dotyczą 13 pacjentów (43\%), natomiast poprawa sprawności jest zauważalna u 12 chorych (40\%). Wyniki „ECOG obecny” pokazują, że powiększyła się prawie dwukrotnie - do 11 - liczba osób sprawnych (37\%) i nie zwiększyła się liczba chorych wymagających opieki pielęgnacyjnej. Na uwagę zasługuje fakt, że 17 osób (57\%) uczestniczy w I linii leczenia, a pozostałe (43\% - prawie połowa) w kolejnych.

Poszukując istotnych zależności między zasobami psychologicznymi pacjentów i zmianami w sprawności funkcjonowania występujących $\mathrm{w}$ procesie leczenia chemioterapią dożylną, dokonano porównania w grupie względem wybranych cech poprzez wykorzystanie analizy wariancji ANOVA (Tab. V). Wyniki prezentowane $\mathrm{w}$ tabeli $\mathrm{V}$ wskazują na istniejące związki między oceną zmian funkcjonowania mierzonych skalą ECOG i CECS S ( $p=0,022)$ oraz LOT-R $(p=0,04)$. Oznacza to, że obiektywnie stwierdzone pogorszenie sprawności funkcjonowania towarzyszy skłonności do pesymizmu, stosowania mechanizmów zaprzeczania i zaprzestawania działań oraz zmianom w zakresie kontroli lęku. Wyniki prezentowane $\mathrm{w}$ tabeli VI wskazują na istniejące związki między kolejną linią leczenia i CECS L ( $p=0,033)$. Oznacza to, że kontrola lęku najsilniej występuje u ludzi, którzy leczeni są w I linii. Każda następna linia leczenia osłabia kontrolę emocjonalną w zakresie lęku, co powoduje, że znacznie łatwiej przychodzi badanym wyrażanie go. Pozostałe badane związki między zasobami osobowymi pacjentów i linią leczenia nie są istotne statystycznie.

Poszukiwania związków między wskaźnikami medycznymi postępu choroby i subiektywną oceną zmian objęły 3 kierunki badania: porównanie wyników ocen dokonywanych 3-krotnie na przestrzeni leczenia $\mathrm{z}$ oceną $\Delta$ ECOG, ocenę zmian klinicznych z oczekiwaniami oraz ocenę $\Delta$ ECOG. Wyniki w tabeli VII wskazują, że na 14 osób, które

Tabela IV - Ocena dynamiki choroby z użyciem parametrów medycznych: sprawności funkcjonowania fizycznego mierzonego skalą ECEG oraz linii leczenia

Table IV - Assess the dynamics of the disease with the use of medical parameters: efficiency of the physical in scale ECEG, and the line of treatment

\begin{tabular}{|c|c|c|}
\hline ECOG - stopień sprawności & ECOG wyjściowy - ilość osób & ECOG obecny - ilość osób \\
\hline $\begin{array}{l}0 \text { - sprawność prawidłowa, zdolność do samodzielnego wykonywania } \\
\text { codziennych czynności }\end{array}$ & $6(20 \%)$ & $11(37 \%)$ \\
\hline $\begin{array}{l}1 \text { - obecność objawów choroby, możliwość chodzenia i wykonywania } \\
\text { lekkiej pracy }\end{array}$ & $12(40 \%)$ & $10(33 \%)$ \\
\hline $\begin{array}{l}2 \text { - zdolność do wykonywania czynności osobistych, niezdolność do } \\
\text { pracy, spędza w łóżku około połowy dnia }\end{array}$ & $5(17 \%)$ & $5(17 \%)$ \\
\hline $\begin{array}{l}3 \text { - ograniczona zdolność wykonywania czynności osobistych, spędza } \\
\text { w łóżku ponad połowę dnia }\end{array}$ & $3(10 \%)$ & 0 \\
\hline 4 - konieczność opieki osoby drugiej, spędza w łóżku cały dzień & $4(13 \%)$ & $4(13 \%)$ \\
\hline 5 - zgon & - & - \\
\hline$\overline{\text { Ocena } \Delta \text { ECOG }}$ & Ilość osób & \\
\hline 1 - pogorszenie & $5(17 \%)$ & \\
\hline 2 - bez zmian & $13(43 \%)$ & \\
\hline 3 - zmiana na lepsze & $12(40 \%)$ & \\
\hline Linia leczenia & Ilość osób & \\
\hline 1 & $17(57 \%)$ & \\
\hline 2 & $9(30 \%)$ & \\
\hline 3 & $4(13 \%)$ & \\
\hline
\end{tabular}


Tabela V - Związki między oceną zmian funkcjonowania mierzonych skalą ECOG a wybranymi parametrami

funkcjonowania psychologicznego (ANOVA)

Table V - Relationships between the assessment of the functioning changes in ECOG scale and selected parameters of psychological functioning (ANOVA)

\begin{tabular}{|c|c|c|c|c|c|c|c|c|}
\hline ocena $\Delta$ EC & & $\mathrm{N}$ & ŚREDNIA & SD & MIN & $\mathrm{ME}$ & MAX & \\
\hline pogorszenie & AIS & 5 & 20,20 & 4,91 & 16,00 & 18,00 & 26,00 & \\
\hline bez zmian & & 13 & 24,15 & 7,24 & 8,00 & 26,00 & 33,00 & \\
\hline poprawa & & 12 & 26,50 & 5,01 & 17,00 & 27,00 & 33,00 & \\
\hline pogorszenie & LOT-R & 5 & 12,18 & 4,52 & 5,00 & 12,00 & 13,00 & $p=0,040$ \\
\hline bez zmian & & 13 & 15,46 & 3,03 & 13,00 & 15,00 & 17,00 & \\
\hline poprawa & & 12 & 20,33 & 4,24 & 20,00 & 22,00 & 24,00 & \\
\hline pogorszenie & GSES & 5 & 28,60 & 4,66 & 23,00 & 28,00 & 36,00 & \\
\hline bez zmian & & 13 & 28,92 & 4,42 & 18,00 & 29,00 & 36,00 & \\
\hline poprawa & & 12 & 30,66 & 7,03 & 19,00 & 29,50 & 45,00 & \\
\hline pogorszenie & CECS G & 5 & 19,80 & 2,28 & 17,00 & 19,00 & 23,00 & \\
\hline bez zmian & & 13 & 16,15 & 5,49 & 8,00 & 16,00 & 27,00 & \\
\hline poprawa & & 12 & 17,50 & 4,66 & 9,00 & 18,00 & 28,00 & \\
\hline pogorszenie & CECS D & 5 & 20,20 & 2,68 & 18,00 & 19,00 & 24,00 & \\
\hline bez zmian & & 13 & 16,76 & 4,28 & 8,00 & 17,00 & 23,00 & \\
\hline poprawa & & 12 & 18,91 & 2,81 & 16,00 & 18,50 & 25,00 & \\
\hline pogorszenie & CECS L & 5 & 19,60 & 3,36 & 15,00 & 20,00 & 24,00 & $p=0,022$ \\
\hline bez zmian & & 13 & 16,07 & 4,34 & 10,00 & 16,00 & 23,00 & \\
\hline poprawa & & 12 & 20,33 & 3,08 & 16,00 & 20,50 & 26,00 & \\
\hline pogorszenie & SWLS & 5 & 24,20 & 2,04 & 21,00 & 24,00 & 26,00 & \\
\hline bez zmian & & 13 & 22,30 & 6,25 & 14,00 & 23,00 & 32,00 & \\
\hline poprawa & & 12 & 25,16 & 4,04 & 19,00 & 25,00 & 31,00 & \\
\hline
\end{tabular}

aktualnie, w trakcie leczenia, spostrzegają u siebie poprawę zdrowia, $11(78,6 \mathrm{~A} \%)$ oczekuje dalszej poprawy po zakończeniu leczenia. Podobnie prezentują się oczekiwania u 14 osób, które zaznaczyły, że objawy choroby są silniejsze - 11 z nich oczekuje, że po chemioterapii nastąpi poprawa zdrowia. Spośród 12 pacjentów, u których zmiany skali ECOG były korzystne, $10(83 \%)$ sądzi, że po leczeniu poczują się lepiej. Na 5 chorych z niekorzystnymi wynikami w ECOG - 4 (80\%)

Tabela VI - Związki między linią leczenia a wybranymi parametrami funkcjonowania psychologicznego (ANOVA) Table VI - Relationships between line of treatment and selected parameters of psychological functioning (ANOVA)

\begin{tabular}{|c|c|c|c|c|c|c|c|c|}
\hline linia leczenia & & $\mathrm{N}$ & ŚREDNIA & $\mathrm{SD}$ & MIN & $\mathrm{ME}$ & MAX & $\mathrm{p}$ \\
\hline 1 & AIS & 17 & 26,00 & 5,36 & 14,00 & 26,00 & 33,00 & \\
\hline 2 & & 9 & 23,11 & 7,76 & 8,00 & 25,00 & 32,00 & \\
\hline 3 & & 4 & 20,75 & 5,50 & 16,00 & 20,50 & 26,00 & \\
\hline$\overline{1}$ & LOT-R & 17 & 28,23 & 4,98 & 16,00 & 27,00 & 37,00 & \\
\hline 2 & & 9 & 27,22 & 11,27 & 14,00 & 22,00 & 48,00 & \\
\hline 3 & & 4 & 24,50 & 0,57 & 24,00 & 24,50 & 25,00 & \\
\hline$\overline{1}$ & GSES & 17 & 30,35 & 4,22 & 23,00 & 29,00 & 38,00 & \\
\hline 2 & & 9 & 28,44 & 8,50 & 18,00 & 27,00 & 45,00 & \\
\hline 3 & & 4 & 28,75 & 0,95 & 28,00 & 28,50 & 30,00 & \\
\hline$\overline{1}$ & CECS G & 17 & 17,41 & 5,39 & 9,00 & 18,00 & 28,00 & \\
\hline 2 & & 9 & 17,55 & 4,41 & 8,00 & 19,00 & 22,00 & \\
\hline 3 & & 4 & 16,25 & 3,77 & 12,00 & 16,00 & 21,00 & \\
\hline$\overline{1}$ & CECS N & 17 & 18,23 & 3,17 & 12,00 & 17,00 & 24,00 & \\
\hline 2 & & 9 & 17,66 & 4,82 & 8,00 & 19,00 & 25,00 & \\
\hline 3 & & 4 & 19,25 & 3,40 & 15,00 & 20,00 & 22,00 & \\
\hline 1 & CECS S & 17 & 19,82 & 4,31 & 10,00 & 21,00 & 26,00 & $\mathrm{p}=0,033$ \\
\hline 2 & & 9 & 17,44 & 2,00 & 14,00 & 18,00 & 21,00 & \\
\hline 3 & & 4 & 14,25 & 4,34 & 10,00 & 13,50 & 20,00 & \\
\hline$\overline{1}$ & SWLS & 17 & 24,94 & 4,84 & 14,00 & 25,00 & 32,00 & \\
\hline 2 & & 9 & 23,66 & 4,60 & 16,00 & 24,00 & 30,00 & \\
\hline 3 & & 4 & 19,00 & 4,39 & 14,00 & 19,00 & 24,00 & \\
\hline$\overline{1}$ & LWO A & 17 & 4,00 & 1,27 & 0,00 & 4,00 & 5,00 & \\
\hline 2 & & 9 & 4,11 & 0,92 & 3,00 & 4,00 & 5,00 & \\
\hline 3 & & 4 & 5,00 & 0,00 & 5,00 & 5,00 & 5,00 & \\
\hline$\overline{1}$ & LWO B & 17 & 4,17 & 1,46 & 0,00 & 5,00 & 5,00 & \\
\hline 2 & & 9 & 4,22 & 0,83 & 3,00 & 4,00 & 5,00 & \\
\hline 3 & & 4 & 5,00 & 0,00 & 5,00 & 5,00 & 5,00 & \\
\hline
\end{tabular}


Tabela VII - Zależności między zobiektywizowanymi i subiektywnymi ocenami stanu zdrowia (N = 30) Table VII - Relationships between objective and subjective evaluation of health status $(\mathbf{N}=30)$

\begin{tabular}{|c|c|c|c|c|}
\hline \multirow[t]{2}{*}{ Zmiany kliniczne (A:B } & \multirow[b]{2}{*}{ liczba osób } & \multicolumn{3}{|c|}{ OCZEKIWANIA (B:C) } \\
\hline & & pogorszenie & bez zmian & poprawa \\
\hline 1 - pogorszenie $(\%)$ & 14 & $2(14,29 \%)$ & $2(14,29 \%)$ & $10(71,43 \%)$ \\
\hline 2 - bez zmian (\%) & 2 & $0(0,00 \%)$ & $1(50,00 \%)$ & $1(50,00 \%)$ \\
\hline 3 - poprawa (\%) & 14 & $3(21,43 \%)$ & $0(0,00 \%)$ & $11(78,57 \%)$ \\
\hline liczba osób & 30 & 5 & 3 & 22 \\
\hline \multicolumn{2}{|l|}{ ocena $\Delta$ ECOG } & \multicolumn{3}{|c|}{ OCZEKIWANIA (B:C) } \\
\hline & liczba osób & pogorszenie & bez zmian & poprawa \\
\hline 1 - pogorszenie (\%) & 5 & $0(0 \%)$ & $1(20,00 \%)$ & $4(80,00 \%)$ \\
\hline 2 - bez zmian (\%) & 13 & $4(30,77 \%)$ & $1(7,69 \%)$ & $8(61,54 \%)$ \\
\hline 3 - poprawa (\%) & 12 & $1(8,33 \%)$ & $1(8,33 \%)$ & $10(83,33 \%)$ \\
\hline liczba osób & 30 & 5 & 3 & 22 \\
\hline \multicolumn{2}{|l|}{ ocena $\Delta$ ECOG } & \multicolumn{3}{|c|}{ ZMIANY KLINICZNE (A:B) } \\
\hline & liczba osób & pogorszenie & bez zmian & poprawa \\
\hline 1 - pogorszenie (\%) & 5 & $2(40,00 \%)$ & $1(20,00 \%)$ & $2(40,00 \%)$ \\
\hline 2 - bez zmian (\%) & 13 & $5(38,46 \%)$ & $1(7,69 \%)$ & $7(53,85 \%)$ \\
\hline 3 - poprawa (\%) & 12 & $7(58,33 \%)$ & $0(0,00 \%)$ & $5(41,67 \%)$ \\
\hline Liczba osób & 30 & 14 & 2 & 14 \\
\hline
\end{tabular}

spodziewa się poprawy samopoczucia (Tab. VII). Oceny dokonywane skalą ECOG przez lekarzy nie są porównywalne z subiektywnymi ocenami objawów klinicznych dokonywanymi przez chorych. Spośród 13 osób, które w skali ECOG otrzymały ocenę „,bez zmian”, tylko 1 (8\%) spostrzega swój stan zdrowia podobnie. 7 pacjentów dostrzega u siebie poprawę, zaś 5 - pogorszenie. Spośród 12 chorych, ocenionych według skali ECOG jako lepiej funkcjonujących, zgadza się z taką opinią 5 (42\%), zaś 7 spostrzega swój stan zdrowia jako gorszy. 5 osób otrzymało oceny ECOG świadczące o pogorszeniu funkcjonowania. $2(40 \%) \mathrm{z}$ nich spostrzega swoje zdrowie gorzej, 2 (40\%) - lepiej, a 1 (20\%) - bez zmian.

Poszukując związków między zasobami osobowymi a obiektywnymi skutkami choroby i leczenia i subiektywnymi ocenami stanu zdrowia, znaleziono kilka istotnych statystycznie zależności. Pokazuje je tabela VIII, z której wynika, że oceniany skalą ECOG stan funkcjonowania pozostaje w odwrotnie proporcjonalnej zależności z akceptacją stanu choroby $(p=0,022)$. Oznacza to, że niższa ocena ECOG (lepsze funkcjonowanie) jest związana z korzystną adaptacją, uznawaniem ograniczeń narzuconych przez chorobę. $\mathrm{Z}$ poziomem satysfakcji z życia mierzonym skalą SWLS pozostaje $\mathrm{w}$ odwrotnie proporcjonalnej zależności poziom aktualnego nasilenia objawów choroby $(p=0,039)$ oraz przewidywanych w przyszłości skutków leczenia $(p=0,06)$. Oznacza to, że pacjenci z wysokim poczuciem zadowolenia z życia mniej dotkliwie odczuwają dolegliwości chorobowe i spodziewają się ich mniejszego nasilenia w przyszłości. Jeszcze jedna silna zależność charakteryzuje wyniki badanej grupy $(p=0,024)$ : pacjenci, którzy słabiej kontrolują emocję lęku, jednocześnie przewidują więcej dolegliwości po zakończeniu leczenia.

Tabela VIII - Związki między zasobami osobowymi a obiektywnymi skutkami choroby mierzonymi skalą ECOG i

subiektywnymi ocenami stanu zdrowia dokonywanymi przez pacjentów (korelacja liniowa Pearsona)

Table VIII - Relationships between personal resources and the objective effects of the disease measured by ECOG scale and subjective health reviews made by patients (Pearson linear correlation)

\begin{tabular}{|c|c|c|c|c|c|c|c|}
\hline & AIS & LOT-R & GSES & CECS Gniew & CECS Depresja & CECS lęk & SWLS \\
\hline \multirow[t]{3}{*}{ ECOG wyjściowy } & $-0,00$ & $-0,01$ & $-0,04$ & $-0,18$ & $-0,19$ & 0,28 & 0,3080 \\
\hline & $\mathrm{N}=30$ & $\mathrm{~N}=30$ & $N=30$ & $\mathrm{~N}=30$ & $\mathrm{~N}=30$ & $\mathrm{~N}=30$ & $\mathrm{~N}=30$ \\
\hline & $p=0,97$ & $p=0,93$ & $p=0,82$ & $p=0,33$ & $p=0,31$ & $p=0,12$ & $p=0,09$ \\
\hline \multirow[t]{3}{*}{ ECOG obecny } & $-0,41$ & $-0,33$ & $-0,18$ & 0,08 & 0,02 & 0,16 & 0,07 \\
\hline & $\mathrm{N}=30$ & $\mathrm{~N}=30$ & $\mathrm{~N}=30$ & $\mathrm{~N}=30$ & $\mathrm{~N}=30$ & $\mathrm{~N}=30$ & $\mathrm{~N}=30$ \\
\hline & $p=0,022$ & $p=0,07$ & $p=0,32$ & $p=0,64$ & $p=0,88$ & $p=0,37$ & $p=0,69$ \\
\hline \multirow[t]{3}{*}{$\overline{\Delta E C O G}$} & $-0,32$ & $-0,24$ & $-0,11$ & 0,20 & 0,16 & $-0,08$ & $-0,17$ \\
\hline & $\mathrm{N}=30$ & $\mathrm{~N}=30$ & $\mathrm{~N}=30$ & $\mathrm{~N}=30$ & $\mathrm{~N}=30$ & $\mathrm{~N}=30$ & $\mathrm{~N}=30$ \\
\hline & $p=0,08$ & $p=0,18$ & $p=0,55$ & $p=0,26$ & $p=0,37$ & $p=0,64$ & $p=0,34$ \\
\hline \multirow[t]{3}{*}{ Ocena A przed rozpoczęciem leczenia } & $\begin{array}{l}-0,34 \\
\end{array}$ & $-0,12$ & $-0,07$ & $\begin{array}{l}-0,09 \\
\end{array}$ & $\begin{array}{l}-0,26 \\
\end{array}$ & $-0,25$ & $\begin{array}{l}-0,02 \\
\end{array}$ \\
\hline & $\mathrm{N}=30$ & $\mathrm{~N}=30$ & $\mathrm{~N}=30$ & $\mathrm{~N}=30$ & $\mathrm{~N}=30$ & $\mathrm{~N}=30$ & $\mathrm{~N}=30$ \\
\hline & $p=0,06$ & $p=0,50$ & $p=0,70$ & $p=0,62$ & $p=0,15$ & $p=0,17$ & $p=0,87$ \\
\hline \multirow[t]{3}{*}{ Ocena B w trakcie leczenia } & $-0,06$ & $-0,21$ & 0,14 & $-0,09$ & $-0,08$ & $-0,17$ & $-0,37$ \\
\hline & $\mathrm{N}=30$ & $\mathrm{~N}=30$ & $N=30$ & $\mathrm{~N}=30$ & $N=30$ & $\mathrm{~N}=30$ & $\mathrm{~N}=30$ \\
\hline & $p=0,75$ & $p=0,26$ & $p=0,44$ & $p=0,62$ & $p=0,64$ & $p=0,35$ & $p=0,039$ \\
\hline \multirow[t]{3}{*}{ Ocena C oczekiwania skutków leczenia } & $-0,04$ & $-0,32$ & $-0,23$ & $-0,27$ & $-0,14$ & $-0,41$ & $-0,48$ \\
\hline & $\mathrm{N}=30$ & $\mathrm{~N}=30$ & $\mathrm{~N}=30$ & $\mathrm{~N}=30$ & $\mathrm{~N}=30$ & $\mathrm{~N}=30$ & $\mathrm{~N}=30$ \\
\hline & $p=0,82$ & $p=0,07$ & $p=0,22$ & $p=0,14$ & $p=0,43$ & $p=0,024$ & $p=0,006$ \\
\hline
\end{tabular}




\section{Omówienie}

Za początek późnej dorosłości większość gerontologów umownie przyjmuje przedział 60-65 lat. Nie znaleziono żadnego wiarygodnego wyznacznika starzenia się, jednak to właśnie w tym wieku zaczynają się uwidaczniać zmiany w funkcjonowaniu psychicznym i fizycznym. W myśl teorii wyczerpania redukcyjnego spadki sprawności dotyczą w większym stopniu procesów bardziej złożonych niż prostych funkcji. Zmniejszające się stymulowanie umysłu oraz ubytki liczby i wydajności neuronów w późnej dorosłości powodują, że obraz rzeczywistości staje się dla człowieka mniej rzetelny [3]. Zatem jego relacje ze światem też stają się mniej precyzyjne.

Pytanie, w jakim stopniu takie rozluźnienie kontaktu ze światem dotyczy pacjentów poddanych chemioterapii, stanowiło inspirację do wykonania charakterystyki psychologicznych zasobów w grupie badawczej. Spośród cech osobowych człowieka na okoliczność badania wybrano takie, które mają związek z motywacją do działań prozdrowotnych. Grupę przebadanych 30 osób charakteryzują przeciętne wyniki $\mathrm{w}$ badanych skalach. W porównaniu z grupami odniesienia: zdrowych i chorych somatycznie ludzi w różnym wieku, wyniki te pozostają na podobnym poziomie lub są nawet nieco wyższe. Badanych cechuje przeciętny optymizm, który pozwala im pozytywnie oceniać własne zasoby radzenia sobie w sytuacji stresowej, siłę zaangażowania, skuteczność, daje im odporność na stresujące wydarzenia życiowe. Akceptowanie stanu choroby obniża dyskomfort psychiczny i uruchamia procesy adaptacji do leczenia.

Grupę charakteryzuje dość wysoki poziom kontroli emocji negatywnych pojawiających się zwykle w sytuacjach trudnych. Może być to wyrazem kluczowej cechy wzorca zachowania pacjentów z chorobą nowotworową, tzw. typu C: zaprzeczania lub tłumienia, zwłaszcza emocji gniewu [15]. Wykazane zatem w badaniu coraz bardziej otwarte ujawnianie lęku i bezradności, występujące podczas kolejnych linii leczenia, należy tłumaczyć w kategoriach głębokich zmian adaptacyjnych, którym poddany jest człowiek w trakcie długotrwałego leczenia choroby nowotworowej.

W zakresie badanych cech osobowych nie dostrzega się takich właściwości, które można by określić jako charakterystyczne dla wieku późnej dorosłości. Badane zasoby osobiste mają nasilenie sprzyjające współpracy w leczeniu. Ich poziom sugeruje także, że sytuacja lecznicza jest przez pacjentów postrzegana jako przyjazna, dająca przestrzeń do pielęgnowania korzystnego przeżywania siebie i świata, a nawet do ujawniania negatywnych emocji.

Przeprowadzenie metaanalizy wyników pozwoliło na wyróżnienie jeszcze dwóch ważnych kwestii w zakresie funkcjonowania starszych ludzi w trakcie chemioterapii: oczekiwań wobec świata oraz dynamiki adaptacji do leczenia.

Zagadnienie oczekiwań rozważane było w kontekście zachowań personelu i rodziny. W aktualnej literaturze przedmiotu oczekiwania pacjentów najczęściej omawiane są poprzez analizę braków, błędów i niedostatków [7]. Ciągle podkreślane jest występowanie przedmiotowego traktowania pacjenta przez personel medyczny, zaniedbywanie prawidłowego informowania o chorobie $i$ leczeniu tłumaczone brakiem czasu, wynikające $\mathrm{z}$ medykalizacji kontaktu lub niedouczenia w zakresie zasad komunikacji [16]. Klasycy zagadnienia „relacja lekarz-pacjent” Sheridan i Radamer podkreślają, że ważne jest dostarczenie pacjentowi istotnych dla zdrowienia informacji [17]. Salmon pisze o znaczeniu płaszczyzny porozumienia w kontekście oczekiwań pacjenta [18]. Według Ratajskiej i Kubicy pacjent oczekuje od personelu medycznego zrozumienia problemów, trosk i obaw [19]. W sytuacji leczenia oczekiwania należy rozumieć w kategorii idealnej wersji wystąpienia zdarzeń - opierają się bowiem nie tylko na posiadanych informacjach i poglądach, ale także na nadziejach pacjenta. Pierwsze badania na temat oczekiwań przeprowadzone przez Israela opublikowano w Polsce już w 1962 roku. Wynikało z nich, że większość pacjentów (49\%) oczekiwała działań medycznych wiążących się $\mathrm{z}$ funkcją ekspresyjną, tylko $18 \%$ - zachowań wiążących się z informowaniem, a na trzecim miejscu były oczekiwania co do funkcji instrumentalnej [20]. Tak zaskakujący rozkład oczekiwań do dziś jest cytowany bez wyjaśnienia, które było bardzo proste: otóż większość pacjentów zakłada „milcząco” biegłość fachową lekarzy w zakresie działań instrumentalnych, dlatego nie uwzględnia tego w wymaganiach. Późniejsze badania pokazały nieco inny procentowy rozkład oczekiwań, który uwzględniał sytuację choroby. Doniesienie Kawczyńskiej-Butrym udowodniło, że w grupie chorych przewlekle $62 \%$ wybrało funkcję ekspresywną, a 39\% - instrumentalną [21]. W niniejszych badaniach $60 \%$ chorych oczekuje od personelu czynności ekspresyjnych (możliwości ujawnienia swoich obaw i potrzeb oraz troski i życzliwości), zaś rzeczowych informacji - 23\%. Niewielu pacjentów zaznaczyło, że chciałoby rozmawiać o problemach związanych z leczeniem (7\%). Natomiast o czynnościach instrumentalnych (praktycznych zabiegach opiekuńczych oraz leczniczych i fachowości przejawiającej się w bezboleśnie prowadzonych interwencjach) wspomniało zaledwie $10 \%$ chorych. Wyjaśnienia takich proporcji w oczekiwaniach, a szczególnie faktu prawie całkowitego pominięcia znaczenia jakości zabiegów, trzeba szukać w podobnym nastawieniu, jakie zidentyfikował Izrael pacjenci zakładają a priori, że umiejętności instrumentalne personel ma. Tak wyrażanej postawie sprzyja akceptacja uciążliwości choroby cechująca badanych chorych hematologicznych, wstrzemięźliwość emocjonalna oraz towarzysząca jej skłonność do fatalistycznego postrzegania rzeczywistości. Bez dodatkowych badań pogłębiających problem trudno jest wyjaśniać fakt, że bardzo niewiele osób chciałoby rozmawiać o problemach związanych z leczeniem. Nie jest on jednak wynikiem wyjątkowym. Heszen-Niejodek przytacza badania Chmielnickiego z 1976 roku przeprowadzone w grupie 1000 osób hospitalizowanych, z których wynika, że nikt nie chciał mieć możliwości współuczestniczenia w decyzjach dotyczących jego osoby [21].

$\mathrm{Na}$ zobiektywizowanych i subiektywnych ocenach funkcjonowania zdecydowano się oprzeć opis dynamiki choroby i leczenia w badanej grupie. Tłumacząc zmieniający się stan fizyczny osób poddanych kolejnym cyklom chemioterapii, warto skorzystać z teorii GAS (Ogólny Zespół Adaptacyjny) Seylego [22]. Badacz zakładał, że stres (w takim wymiarze należy spostrzegać chorobę) uruchamia energochłonne mechanizmy przystosowawcze. Długotrwałe leczenie choroby nowotworowej powoduje, że w pewnym momencie organizm człowieka zaczyna czerpać z życiowej energii głębokiej. Seyle 
identyfikuje ją z takimi zasobami energetycznymi, których nie da się zregenerować. W sytuacji gdy rozwój choroby jest zatrzymany, najczęstszym mechanizmem uruchamianym przez chorego jest tzw. „depresja z wyczerpania”. Ma ona ważne zadanie adaptacyjne, które służy ochronie zasobów energetycznych w wyniku wyhamowania funkcji życiowych człowieka we wszystkich jego sferach. Inna jest reakcja chorych nowotworowych, których choroba postępuje pomimo towarzyszącego jej leczenia. Progres choroby, nawet jeśli jest przerywany okresami regresu, nie daje możliwości wypoczynku i regeneracji zasobów adaptacyjnych. Stosuje się bowiem kolejne linie leczenia w celu ratowania życia i zdrowia chorych na miarę sił pacjenta i jego oczekiwań [5]. Zmiany wymuszane $\mathrm{w}$ procesie adaptacji dotyczą wielu wymiernych wskaźników: fizycznych i psychicznych, pozostających ze sobą w związku. Te statystycznie istotne wzajemne relacje w niniejszym badaniu pokazują porównania wyników skal ECOG, linii leczenia oraz zmian w zakresie satysfakcji z życia, nadziei na przyszłość i kontroli emocji lęku. Skłonność do tłumienia emocji jest uznawana przez badaczy za względnie stałą cechę osób mających tendencję do sztywnego przestrzegania obowiązujących norm społecznych i jako taka jest kojarzona z genezą chorób nowotworowych. Zmiana w zakresie kontroli emocji może być tłumaczona głębokimi psychologicznymi przemianami. W początkowych etapach leczenia badani pacjenci poddawani chemioterapii hamują wyrażanie negatywnych emocji gniewu, przygnębienia i lęku, które przeżywane są zwykle w życiowych sytuacjach kryzysu. Różnią się w tym diametralnie od pacjentów zakwalifikowanych do leczenia dializami z powodu TNN, którzy najsłabszą kontrolę emocjonalną przejawiają właśnie w początkowym etapie leczenia [23]. W dodatku, wśród dializowanych to starsi pacjenci są skłonni do ujawniania gniewu [24]. W badanej grupie starszych pacjentów hematologicznych ekspresja emocji dotyczy późnych etapów leczenia, kiedy chorzy ujawniają lęk. Tak przejawiające się rozluźnienie trwałych mechanizmów osobowościowych należy wiązać ze stopniową kachektyzacją, osłabieniem, utratą energii życiowej występującymi wraz z kolejnymi liniami leczenia [5, 22].

Na zakończenie analizy trzeba zwrócić uwagę na sposób interpretowania rzeczywistości przez badanych. Okazuje się, że reagują oni słabszym akceptowaniem choroby (jej uciążliwości i narzuconych ograniczeń) tylko w sytuacji stwierdzonego aktualnie spadku sprawności (ECOG). Jednak te obiektywnie mierzone zmiany mówiące o pogorszeniu funkcjonowania nie kształtują subiektywnie spostrzeganych przez chorych zmian klinicznych oraz oczekiwań od leczenia chemioterapią dożylną. Bez względu na spostrzeganą jakość przebiegu choroby - pogorszenie stanu zdrowia, zmiany na lepsze lub brak zmian - większość pacjentów oczekuje poprawy w leczeniu.

\section{Wnioski}

Badania grupy 30 pacjentów w wieku 60+ będących $\mathrm{w}$ procesie leczenia choroby hematologicznej chemioterapią dożylną pozwoliły na przeprowadzenie metaanalizy i wyciągnięcie wniosków:
1. Grupę przebadanych charakteryzują przeciętne wyniki w zakresie zasobów osobowych. Chorych cechuje przeciętny optymizm, który pozwala im pozytywnie oceniać własne zasoby radzenia sobie w sytuacji stresowej, siłę zaangażowania, skuteczność, daje im odporność na stresujące wydarzenia życiowe. Akceptowanie stanu choroby obniża dyskomfort psychiczny i uruchamia procesy adaptacji do leczenia. Tak jak inne grupy chorych nowotworowych, pacjenci są wstrzemięźliwi emocjonalnie, pokorni i cierpliwi w zachowaniu.

2. W zakresie oczekiwań określonych zachowań od świata badana grupa nie różni się od innych, przewlekle leczonych pacjentów. Od personelu medycznego pacjenci oczekują czynności ekspresyjnych i informacyjnych. Niewielu chorych chce rozważać problemy związane z leczeniem. Także od rodziny pragną życzliwego towarzyszenia im w leczeniu.

3. Obraz dynamiki choroby opracowano, korzystając z 2 kategorii: zobiektywizowanej (skala ECOG i linia leczenia) oraz subiektywnej (oceny pacjentów dotyczące zmian stanu zdrowia). Na przestrzeni leczenia uzyskano obraz zmieniającego się stanu fizycznego pacjentów i towarzyszących im zmian w funkcjonowaniu psychicznym.

4. Optymizm życiowy oraz kontrola emocji lęku są związane z zobiektywizowanymi zmianami w kierunku poprawy sprawności. Kolejne linie leczenia wywołują u chorych silniejszą ekspresję lęku.

5. Zobiektywizowane zmiany w zakresie sprawności funkcjonowania w żaden sposób nie kształtują subiektywnie spostrzeganych przez chorych zmian klinicznych oraz oczekiwań od leczenia. Wynika z tego, że oceny dokonywane skalą ECOG przez lekarzy nie są porównywalne z subiektywnymi ocenami objawów klinicznych dokonywanymi przez chorych.

6. Istnieją istotne związki między obiektywnymi i subiektywnie ocenianymi objawami skutków choroby i leczenia a wybranymi parametrami funkcjonowania psychologicznego. Stopień akceptacji choroby jest proporcjonalny do aktualnego stopnia sprawności. Natomiast satysfakcja z życia oraz silniejsza kontrola emocji lęku sprzyja pozytywnym oczekiwaniom co do skutków leczenia.

7. Większość pacjentów, bez względu na przebieg choroby, oczekuje poprawy w leczeniu.

\section{Podsumowanie}

Najważniejszą rolę w procesie leczenia choroby hematologicznej odgrywa chemioterapia dożylna. Leczenie chemioterapią doustną w większości przypadków, z wyjątkiem niektórych schematów terapii szpiczaka plazmatycznego, pozostaje leczeniem paliatywnym. Podobnie radioterapia w hematologii, z wyjątkiem nielicznych postaci chłoniaka Hodgkina, jest leczeniem uzupełniającym lub paliatywnym przeciwbólowym. W chorobach hematologicznych inaczej niż w onkologii guzów litych pacjent często już w chwili rozpoznania znajduje się w stanie ogólnym ocenianym wg różnych skal wydolności fizycznych jako ciężki. Chory taki poddany radykalnemu leczeniu chemioterapią dożylną ma szansę uzyskać 
remisję choroby, a tym samym znaczącą poprawę stanu wydolności fizycznej. Do niedawna intensywna chemioterapia rezerwowana była dla chorych w młodszym wieku z dobrą wydolnością narządową. Pacjenci starsi kwalifikowani byli do terapii objawowej, paliatywnej. Obecnie coraz powszechniej stosowane jest inne niż wiek kryterium podziału na grupy stratyfikacyjne, kryterium to obejmuje skalę wydolności narządów i sprawności ogólnej, co szczególnie zauważalne jest np. w przyporządkowaniu starszych chorych z rozpoznaniem przewlekłej białaczki limfatycznej do grup ,go go", ,slow go" i ,,no go".

Zaprezentowany opis funkcjonowania psychofizycznego starszych pacjentów podczas leczenia dożylną chemioterapią wyjaśnia, że pomimo obciążającego leczenia oczekiwania chorych są związane $\mathrm{z}$ nadzieją na lepsze samopoczucie i stanowią podstawę zachowań zdrowotnych.

\section{Wkład autorów/Authors' contributions}

Według kolejności.

\section{Konflikt interesu/Conflict of interest}

Nie występuje.

\section{Finansowanie/Financial support}

Nie występuje.

\section{Etyka/Ethics}

Treści przedstawione w artykule są zgodne $\mathrm{z}$ zasadami Deklaracji Helsińskiej, dyrektywami EU oraz ujednoliconymi wymaganiami dla czasopism biomedycznych.

Badania własne zostały przeprowadzone zgodnie $\mathrm{z}$ zasadami Dobrej Praktyki Klinicznej i zaakceptowane przez lokalną Komisję Bioetyki, a ich uczestnicy wyrazili pisemną zgodę na udział.

\section{PIŚMIEN N I C T W O/R EFERENCES}

[1] Cyceron MT. Katon Starszy o starości. Warszawa: Wydawnictwo Literackie; 1995.

[2] Stuart-Hamilton J. Psychologia starzenia się. Poznań: Wydawnictwo ZYK i S-KA; 2000.

[3] Leszczyńska I, Żychlińska M. Zyski i straty w wieku późnej dorosłości - fenomen słuchaczy Uniwersytetu Trzeciego Wieku. W: Bielawska-Batorowicz E, Dudek B, reds. Teoria zachowania zasobów. Polskie doświadczenia. Łódź: Wydawnictwo Uniwersytetu Łódzkiego; 2012. p. 135-154.

[4] Ottmann FO, Wassmann FB, Pfeifer FH, GMALL Study Group. Imatinib Compared With Chemotherapy as FrontLine Treatment of Elderly Patients With Philadelphia
Chromosome-Positive Acute Lymphoblastic Leukemia (Ph + ALL). www.interscience.wiley.com (Dostęp 11.04.2007).

[5] Gatttermann N. Myelodysplastic syndromes: clinical aspects. Hematology Education 2012;6:253-260.

[6] Łacko A, Gisterek I, Krzemieniecki K. Zespół wyniszczenia nowotworowego. W: Krzemieniecki K, red. Leczenie wspomagające w onkologii. Poznań: Termedia; 2008. p. 76-91.

[7] Grabińska K, Szewczyk-Cisek I, Hernik P, Mykała-Cieśla J, Kaziród D. Problemy i potrzeby psychosocjalne pacjentów poddanych chemioterapii onkologicznej. Psychoonkologia 2011;2:39-47.

[8] Antonovsky A. Rozwikłanie tajemnicy zdrowia. Jak radzić sobie ze stresem i nie zachorować. Warszawa: Fundacja IPN; 1999.

[9] Csikszentmihalyi M. Urok codzienności. Psychologia emocjonalnego przepływu. Warszawa: Wydawnictwo CIS i WAB; 1998.

[10] Zimbardo PG. Psychologia i życie. Warszawa: Wydawnictwo Naukowe PWN; 1999.

[11] Seligmann MEP, Rashid T, Parks A. Positive psychoterapy. American Psychologist 2006;61(8):774-788.

[12] Zawadzka B, Będkowska-Korpała B. Bilansowanie zysków i strat w procesie adaptacji do choroby i leczenia u pacjentów hematologicznych. W: Bielawska-Batorowicz E, Dudek B, reds. Analiza w oparciu o teorię zachowania zasobów. Teoria zachowania zasobów. Polskie doświadczenia. Łódź: Wydawnictwo Uniwersytetu Łódzkiego; 2012. p. 155-165.

[13] Dmoszyńska A, Robak T. Podstawy hematologii. Lublin: Czelej Sp z o.o; 2008. p. 34-36.

[14] Juczyński Z. Narzędzia pomiaru w promocji I psychologii zdrowia. Warszawa: Pracownia Testów Psychologicznych PTP; 2001.

[15] Watson M, Greer S, Bowden L, Gorman C, Robertson B, Bliss JM, Tunmore R. Relationships between emotional control, adjustment to cancer and depression and anxiety in breast cancer patients. Psychological Medicine 1991;21:51-57.

[16] Zieniuk A. Oczekiwania pacjenta onkologicznego wobec personelu medycznego. Psychoonkologia 2009;1-2:17-27.

[17] Radmacher S. Sheridan Ch. Psychologia zdrowia. Wyzwanie dla biomedycznego modelu zdrowia. Warszawa: Instytut Psychologii Zdrowia; 1998.

[18] Salmon P. Psychologia w medycynie wspomaga współpracę z pacjentem i proces leczenia. Gdańsk: Gdańskie Wydawnictwo Psychologiczne; 2002.

[19] Ratajska A, Kubica A. Co leży u podłoża złej współpracy lekarz-pacjent?.- spojrzenie psychologa. Via Medica 2010;5(2):84-87.

[20] Izrael J. Socjopsychiczne środowisko szpitala. W: Sokołowska M, red. Badania socjologiczne w medycynie. Warszawa: Książka i Wiedza; 1969.

[21] Heszen-Niejodek I. Lekarz i pacjent. Badania psychologiczne. Kraków: Seria Selekt Uniwersitas; 1992.

[22] Style H. Stres okiełznany. Warszawa: Państwowy Instytut Wydawniczy; 1977.

[23] Zawadzka B, Bętkowska-Korpała B, Kasprzyk S, Gierowski JK. Zależność między czasem leczenia dializami a wybranymi wskaźnikami adaptacji chorych do sytuacji przewlekłej choroby. Konferencja Sekcji Medycyny Psychosomatycznej pt. „Ku lepszemu rozumieniu swoich psychicznych i somatycznych wartości”; 2008. Poster.

[24] Zawadzka B, Bętkowska-Korpała B, Kasprzyk S, Gierowski JK. Ekspresja emocjonalności w procesie leczenia hemodializami. VII Ogólnopolska Konferencja Naukowa Sekcji Psychologii Zdrowia Polskiego Towarzystwa Psychologicznego pt. Psychologia zdrowia - konteksty i pogranicza; 2009. Poster. 